УДК 351.72:338.43

DOI: https://doi.org/10.37320/2415-3583/11.16

Поперечний C.I.

кандидат економічних наук, доцент,

Львівський національний університет ветеринарної медицини та біотехнологій імені С.3. Гжицького

ORCID: https://orcid.org/0000-0003-0702-6281

Саламін O.C.

кандидат економічних наук, доцент,

Львівський національний університет ветеринарної медицини та біотехнологій імені С.3. Гжицького

ORCID: https://orcid.org/0000-0001-5388-3247

\title{
АКТУАЛЬНІ ПРОБЛЕМИ ДЕРЖАВНОГО РЕГУЛЮВАННЯ СІЛЬСЬКОГО ГОСПОДАРСТВА УКРАЇНИ
}

Метою статті є обтрунтування способів удосконалення державного регулювання сільського господарства України в умовах активізачії міжнародних інтеграційних проиесів. Актуальність дослідження визначається несформованістю загальноприйнятих підходів до розроблення та здійснення державної регуляторної політики. Застосовувалися загальноприйняті методи досліджень. Монографічний метод використано для вивчення проблем розроблення регуляторної політики, статистичного аналізу - для дослідження волатильності иін на продукцію та їхнього впливу на обсяги ї̈ виробництва. Результати досліджень полягають у зіставленні різних способів державного регулювання сільського господарства. Обірунтована доиільність сприяння державною регуляторною політикою формуванню саморегулівних економічних систем, у яких без прямого державного регулювання формувалися би прийнятні і стабільніші иіни. Практична значущість полягає у можливості використання запропонованих способів регулювання сільського господарства державними органами управління галуззю та суб 'єктами господарювання.

Ключові слова: державне регулювання сільського господарства, саморегулівні економічні системи, волатильність изін, регулювання цін, державна фінансова підтримка сільського господарства, фермерські господарства.

Постановка проблеми. Проблеми розроблення та здійснення державної регуляторної політики в аграрній сфері економіки України складні та багатопланові. Зумовлюється це історичною особливістю розвитку вітчизняного сільського господарства і на цій основі значною мірою відмінністю цілей регуляторної політики порівняно з поширеними підходами у більшості економічно розвинутих країн. В умовах міжнародних інтеграційних процесів проблеми посилюються намаганнями привести вітчизняну державну політику регулювання сільського господарства у відповідність із принципами, визначеними СОТ та загальною спрямованістю спільної аграрної політики Європейського Союзу. Таке наближення часто здійснюється без належного урахування особливостей сільського господарства України, стратегічних цілей його розвитку та завдань, які при цьому повинні вирішуватись.

Аналіз останніх досліджень i публікацій. У більшості наукових публікацій переважає критика існуючої системи державного регулювання сільського господарства. Така критика, як правило, поєднується із вивченням, узагальненням та запозиченням зарубіжного досвіду регулювання $[4 ; 5$; $7 ; 10]$. Здійснюється порівняльний аналіз обсягів прямої фінансової підтримки в економічно розвинутих країнах та в Україні [7]. Одностайність уче- них у критиці політики державного регулювання сільського господарства поєднується з різними думками щодо способів іiї удосконалення. В умовах ринкової економіки основним регулятором виробництва $\epsilon$ ціна. Тому у багатьох публікаціях обгрунтовується необхідність державного регулювання цін на сільськогосподарську продукцію [5; 11]. Альтернативні погляди полягають у необхідності відмови від прямого державного впливу на ціну [9]. Звертається увага на створення прозорих і зрозумілих схем регулювання [4]. Дискутується проблеми надмірної концентрації сільськогосподарського виробництва в Україні [9; 12]. Загальноприйнятих підходів до удосконалення системи державного регулювання сільського господарства не сформовано.

Метою статті $\epsilon$ розроблення практичних рекомендацій щодо удосконалення державного регулювання сільського господарства в умовах міжнародної інтеграції України.

Виклад основного матеріалу. У вітчизняних наукових виданнях усі процеси, пов'язані з державним регулюванням сільського господарства, намагаються пояснити на основі різних відомих економічних теорій. До уваги не бралося і загалом не береться те, що поняття "ринкова економіка" є абстрактним, і за окремих загальних рис у кожній країні формується своя модель такої економіки. 
У більшості економічно розвинутих країн ринкові відносини й адекватна рівню їхньої сформованості система державного регулювання сільського господарства формувались еволюційно протягом тривалого історичного періоду. По мірі зміни обставин регуляторна політика модифікувалася. Прикладом цього є розроблення та здійснення Спільної аграрної політики Європейського Союзу. На етапі розроблення і прийняття Спільної аграрної політики Європа не була самодостатньою щодо забезпечення сільськогосподарською продукцією. Високі темпи розвитку промисловості поєднувались із відставанням обсягів виробництва продовольчих товарів, що зумовлювало стійкий попит на них та високі ціни. Переваги високих цін на сільськогосподарську продукцію використовували посередницькі структури, які, як і в Україні, закупляли ії у виробників за монопольно низькими цінами. Це зумовлювало помітно нижчі доходи сільських жителів порівняно з міськими й активізовувало процеси урбанізації. Подолати тенденцію зменшення чисельності сільських жителів частково можна було лише шляхом забезпечення прийнятного рівня життя зайнятих у сільському господарстві. Альтернативою збільшенню обсягів виробництва власної продукції сільського господарства могло бути лише посилення іiі імпорту і продовольчої залежності від інших країн. 3 урахуванням цього Спільна аграрна політика на етапі iї започаткування відповідно до Римського договору (1956 р.) спрямовувалася на забезпечення населення продовольчою продукцією за доступними цінами; гарантування забезпечення населення країн - членів співтовариства якісним продовольством за рахунок власного виробництва сільськогосподарської продукції; стабілізацію ринків агропродовольчої продукції, захист виробників і споживачів від зовнішніх чинників; забезпечення прийнятного рівня життя для зайнятих у сільському господарстві, зокрема через збільшення їхніх доходів; забезпечення раціонального розвитку аграрного виробництва й оптимального використання факторів виробництва, передусім праці; підвищення продуктивності сільського господарства шляхом підтримки технічного прогресу. Нині в умовах достатніх обсягів виробництва сільськогосподарської продукції, iï надлишків та посилення конкуренції регуляторна політика спрямовується на квотування обсягів виробництва, сприяння розвитку сільських територій, екологічну безпеку, збереження ароландшафтів тощо. Характерними ії ознаками є відмова від прямих субсидій та цінової підтримки.

Проблеми регуляторного впливу держави після ліквідації командної економіки і становлення ринково орієнтованої економічної системи $\epsilon$ специфічними, характерними лише для післясоціалістичних країн. Такими специфічними, осо- бливо актуальними є проблеми обгрунтування i сприяння розвитку прийнятних організаційних форм суб'єктів господарювання. В Україні досі не завершено трансформаційні процеси, і лише у порядку постановки проблеми вченими аналізуються організаційні форми, які слід підтримувати державною політикою. Загальна невизначеність поєднується з розробленням та здійсненням програм державної підтримки фермерських господарств, спрощенням процедури їх створення, можливістю створення фермерського господарства без реєстрації як юридичної особи. Однак це не забезпечило перетворення фермерських господарств на основних виробників сільськогосподарської продукції, а привело до створення шляхом оренди i суборенди особливо великих господарських структур. Намітилися тенденції інвестування коштів несільськогосподарськими суб'єктами господарювання у сільське господарство і виникнення великомасштабних агроформувань холдингового типу. Виникає особливе, досі не відоме у світовій економічній історії явище - формується олігополістичне, а у більш віддаленій перспективі шляхом розподілу і перерозподілу ринку воно перетворюватиметься у близьке до монополістичного, ринкове середовище в аграрному секторі. Сільськогосподарське виробництво відривається від сільських населених пунктів, зростає безробіття у селах, посилюються соціальні проблеми.

Часто перспективи виникнення та розвитку фермерських господарств практиками господарювання пов'язується із їх фінансовою підтримкою, а рівень наближення державної регуляторної політики у аграрній сфері до такої ж у країнах ЄС оцінюється обсягами такої підтримки. Обсяги прямої державної підтримки й умови, що визначають можливості її отримання, $є$ вагомими чинниками започаткування і розвитку фермерських господарств. Напрями фінансової підтримки фермерських господарств визначаються багатьма регуляторними актами. Розпорошеність коштів між програмами, коригування обсягів підтримки за кожною з них протягом року, несвоєчасне доведення інформації про обсяги підтримки не забезпечували належної ефективності такої підтримки. Інформація про можливі суми фінансової підтримки до суб'єктів господарювання часто доводилась із таким запізненням, за якого вони не могли на основі цієї підтримки розробляти можливі у короткотерміновому ринковому періоді заходи і навіть оформити документи для іiі одержання. Сама процедура документального оформлення фінансової підтримки складна і неприйнятна для фермерських господарств, де відсутні фахівці відповідного профілю.

Державна фінансова підтримка здійснюється на конкурсних засадах. Конкурсний відбір фермерських господарств для надання державної 




\section{Рисунок 1 - Індекси цін реалізації продукції сільськогосподарськими підприсмствами України, у відсотках до попереднього року}

Джерело інформаџії: дані Державної служби статистики України [6, с. 197]

фінансової підтримки передбачає використання насамперед таких показників, як гарантії повернення коштів, ефективність і окупність інвестиційно-інноваційних проектів. Вищі гарантії повернення і вища окупність проектів досягається в ефективніших великих фермерських господарствах. Через це саме на них спрямовується державна фінансова допомога. Тому вона посилює диференціацію фермерських господарств, не сприяє розвитку невеликих за розміром, які найбільше потребують такої допомоги. При цьому завдяки лише фінансовій підтримці виникають господарства, визначальним мотивом поведінки власників яких $\epsilon$ орієнтація насамперед на цю фінансову підтримку. В умовах скорочення обсягів фінансової підтримки такі господарства, як правило, ліквідовувалися. Цьому сприяло спрямування державної регуляторної політики більшою мірою на лібералізацію процесів утворення фермерських господарств, що провокувало їх започаткуванню часто випадковими особами без належного досвіду і необхідних для цього умінь.

Під час аналізу проблем державного регулювання сільського господарства і сприяння розвитку прийнятних організаційно-правових форм серед практиків господарювання та вчених-економістів дискутуються різні, у тому числі і крайні погляди, включаючи неперспективність фермерства, його неприйнятність для вітчизняного сільського господарства. До уваги не беруться чинники середовища, у якому вони функціонують, основним з яких є стан ринку. Порівняно з іншими організаційно-правовими формами господарювання тут вагомішими $€$ мотиваційні чинники господарської поведінки власників. Ця організа- ційно-правова форма господарювання забезпечує поєднання в одній особі власника майна, працівника та менеджера, чим досягається найвищий рівень стимулювання у досягненні належних результатів. Свідченням цього є переважно вища рентабельність сільськогосподарського виробництва у фермерських господарствах України, ніж у господарствах, створених за іншими організаційно-правовими формами. Фермерські господарства оперативно реагують на кон'юнктуру ринку і показники, що характеризують розвиток фермерських господарств, можуть бути індикаторами привабливості агробізнесу та можливостей його провадження суб'єктами господарювання. Вони відображають вплив як ринкових важелів, так і державної регуляторної політики.

Визначальний регуляторний вплив на суб'єктів господарювання має ринковий механізм. Важелі державного регуляторного впливу лише частково послаблюють або посилюють вплив ринкового механізму, основним елементом якого є ціна. Ціни визначають темпи і пропорції розвитку галузей. Вони можуть забезпечити як процвітання, так і банкрутство підприємств. Без належної сформованості ринкових відносин, монополізації ринку окремими структурами не забезпечується еквівалентність товарообмінних операцій. У гірших умовах опиняються сільськогосподарські товаровиробники. В особливо складних умовах опиняються невеликі виробники, які самостійно не можуть формувати власних каналів розподілу. Через неналежну сформованість інфраструктури аграрного ринку вони не можуть навіть вибирати прийнятних маркетингових каналів на альтернативних засадах. Саме це $є$ основною передумовою 
становлення і розвитку особливо великих структур у сільському господарстві, які самостійно здійснюють усі збутові, переважно експортні операції, обминаючи місцеві заготівельні організації, які монополізують ринок. Великі підприємства, як правило, орієнтуються на ціни зовнішнього ринку. Ціновий диспаритет не сприяє розвитку підприємств, які орієнтуються на внутрішній ринок. При цьому послаблюється стимулюючий вплив державної фінансової підтримки. Через нееквівалентні відносини така підтримка переливається у суміжні з сільським господарством галузі. У таких умовах зрозумілими є намагання здійснювати державне регулювання цін.

За роки реформ застосовувались різні способи цінового регулювання, які включали індексацію закупівельних цін на сільськогосподарську продукцію з урахуванням темпів інфляції, обмеження рівня рентабельності посередницьких організацій, затвердження мінімально можливого рівня закупівельної ціни, здійснення державних товарних та фінансових інтервенцій. Жоден із цих способів не забезпечував ні формування цін на сільськогосподарську продукцію на рівні, достатньому для належної окупності здійснених інвестицій, ні стабілізації цін. Характерною особливістю ціноутворення на сільськогосподарську продукцію в Україні є високий рівень цінової волатильності, адаптуватися до якого не можуть суб'єкти господарювання. Наприклад, у 2015 році ціни на яйця порівняно з 2014 роком зросли на 67,5\%, а у 2016 році їхній рівень становив лише 83,5\% порівняно 3 рівнем попереднього року (рис. 1).

Особливо руйнівний вплив такі ціни мають на капіталомісткі галузі 3 тривалою окупністю капіталу. Через високу волатильність і невизначеність очікуваного рівня ціни та пов'язану 3 цим ризиковість господарської діяльності неможливо розробляти бізнес-плани та інвестиційні проекти, залучати банківські кредити. Свідченням цього $\epsilon$ хронічне скорочення поголів'я корів в умовах державного дотування збільшення загального поголів'я великої рогатої худоби.

Проблеми недостатньо результативних зусиль у сфері державного регулювання цін нині посилюються стримуванням такого регуляторного впливу на ціни положеннями СОТ. Не сприймаючи ідеї всесильності ринку і вирішення ним усіх проблем, які нагромадились, слід зазначити, що ринок виконує функцію стабілізації цін. Результативніший вплив на загальний рівень стабілізації цін порівняно з прямим державним втручанням у ціноутворення матимуть зусилля державних органів, спрямовані на формування саморегулівних ринкових структур.

Уже на початкових етапах становлення ринкових відносин у більшості європейських країн формувалися збутові кооперативи, завдяки яким вдавалося обминати заготівельні структури, що монополізували ринок і диктували закупівельні ціни. Пізніше такі кооперативи розширювали сфери діяльності, здійснювали переробку продукції i ïi доведення до споживачів. Виникали інтегровані структури, у яких без державного втручання формувалися прийнятні для усіх учасників ціни. Такі підходи застосовувалися навіть у колишньому Радянському Союзі у кінці 70-х років минулого століття, коли створювалися кооперовані міжгосподарські та інтегровані агропромислові системи. Їхня доцільність в умовах планового ціноутворення і такого ж визначення обсягів реалізаціїпродукціїнинівидаєтьсядивною. Це був досвід аграрних перетворень, доцільність яких $є$ очевидною нині.

В Україні тривалий час здійснюється державна підтримка обслуговуючих кооперативів. Однак пропагуються переважно обслуговуючі кооперативи, які надають технічні і технологічні послуги. Проблеми налагодження у таких кооперативах переробки і реалізації продукції залишаються у тіні. Без цього переваги обслуговуючих кооперативів малопомітні. Заготовлена продукція кооперативами збувається на наявні переробні підприємства за тими цінами, за якими їі виробники можуть самостійно іï збувати без участі у господарській діяльності обслуговуючого кооперативу.

Доцільність багатофункціональних обслуговуючих кооперативів посилюється в умовах активізації міжнародних інтеграційних процесів України. Крім цін, у таких кооперативах можуть узгоджуватися вимоги до сировини, ознаки, необхідні для виробництва конкурентоспроможної на зовнішньому ринку продукції. Без цього втрачаються конкурентні позиції виробників переробленої продукції. На внутрішньому ринку зростає частка такої імпортної продукції. У експорті переважає сировинна продукція. Переважно проявляються негативні ознаки міжнародної інтеграції. Для подолання такої тенденції слід сконцентрувати пряму державну фінансову підтримку на фінансуванні інвестиційних проектів, які передбачають організацію:

- виробництва учасниками обслуговуючого кооперативу сировини, що відповідає міжнародним стандартам і санітарним вимогам;

- створення в обслуговуючому кооперативі потужностей із переробки цієї сировини і виробництва конкурентоспроможної на зовнішньому ринку продукції.

Для державного контролю за цільовим характером використання коштів фінансової підтримки держава може до завершення термінів реалізації проекту залишатися власником придбаних за ці кошти засобів виробництва. Після цього ці засоби слід передавати на баланси підприємств або збільшення їхньої пайової участі в активах коопе- 
ративу. Виникатимуть і певний період часу існуватимуть системи державно-приватного партнерства, що дасть змогу узгоджувати цілі державної підтримки 3 підприємницькими цілями суб'єктів господарювання. Крім того, може бути подолана загальна тенденція розпорошування коштів державної підтримки. Вони зосереджуватимуться і спрямовуватимуться на досягнення пріоритетних цілей розвитку сільського господарства.

Висновки. Проблеми розроблення і здійснення складної та багатопланової державної регуляторної політики в аграрному секторі економіки України аналізуються та дискутуються у наукових виданнях. Пропозицій щодо іiі удосконалення обгрунтовуються різними економічними теоріями та світовим досвідом, часто без належного ураху- вання стану вітчизняного сільського господарства і завдань, які слід вирішувати регуляторною політикою. Переважають пропозиції щодо збільшення обсягів прямої фінансової підтримки і державного регулювання цін. Спроби державного регулювання цін на сільськогосподарську продукцію не забезпечували очікуваних результатів. Через високу волатильність цін і неможливість адаптації до них пріоритетно розвиваються особливо великі за розмірами суб'єкти господарювання холдингового типу, які зорієнтовані на зовнішні ринки, де ціни стабільніші. Значною мірою ці проблеми можуть вирішуватися спрямуванням державної регуляторної політики на формування й удосконалення організаційної побудови ринку, створення саморегулівних ринкових систем.

\section{Список використаних джерел:}

1. Бабенко А.Г., Бондаревська К.В. Шляхи вдосконалення державного регулювання аграрного сектора економіки. Проблеми економіки. 2014. № 3. С. 54-59.

2. Галицький О.М., Лівінський А.І., Дяченко О.П. Організаційно-економічний механізм державного регулювання аграрного виробництва в Україні. Інвестииїі: практика та досвід. 2019. № 3. С. 93-98.

3. Гончарук I.В., Томашук I.В. Державне регулювання розвитку ресурсного потенціалу сільських територій: загальні аспекти. Економіка. Фінанси. Менеджмент: актуальні питання науки і практики. 2018. № 4. С. 19-30.

4. Онєгіна В.М., Шибаєва Н.В. Інституційна основа аграрної політики: українські реалії й досвід США та ЄС. Економіка АПК. 2016. № 1. С. 17-23.

5. Россоха В.В., Шарапа О.М. Інституційне забезпечення управління господарською діяльністю аграрних підприємств. Економіка АПК. 2016. № 10. С. 73-82.

6. Сільське господарство України: статистичний збірник. Київ: Державна служба статистики України, 2019.235 с.

7. Фурман І.В., Пронько Л.М. Формування державної програми підтримки підприємств-агровиробників України з урахуванням світового досвіду. Економіка АПК. 2019. № 11. С. 85-89.

8. Шибаєва Н.В., Квятко Т.М. Еволюція спільної аграрної політики ЄС. Вісник Харківського національного технічного університету сільського господарства імені Петра Василенка. 2015. Вип. 162. С. 306-315.

9. Шубравська О.В. Агропродовольчий розвиток України в контексті глобальних викликів. Економіка АПК. 2014. № 7 C. 52-58.

10. Юрченко А.Д. Державне регулювання аграрної сфери США. Економіка АПК. 2016. № 1. С. 92 - 96.

11. Bondarevska K. State regulation as a factor of sustainable economic development. MEST Journal. 2014. Vol. 2. №. 2. P. 23-31.

12. Perepeczko B. Agriculture in the contemporary social mirror. The central european journal of social sciences and humanities. 2005. № 3(128). P. 80-87.

\section{References:}

1. Babenko A.G., Bondarevs'ka K.V. (2014). Shljahy vdoskonalennja derzhavnogo reguljuvannja agrarnogo sektora ekonomiky [Ways to improve state regulation of the agricultural sector of the economy]. Problemy ekonomiky - . Problems of economy. № 3, pp. 54-59 [in Ukrainian].

2. Galyc'kyj O.M., Livins'kyj A.I., Djachenko O.P. (2019). Organizacijno-ekonomichnyj mehanizm derzhavnogo reguljuvannja agrarnogo vyrobnyctva v Ukrai'ni [Organizational and economic mechanism of state regulation of agricultural production in Ukraine]. Investycii': praktyka ta dosvid - Investment: practice and experience. № 3, pp. 93-98 [in Ukrainian].

3. Goncharuk I.V., Tomashuk I.V. (2018). Derzhavne reguljuvannja rozvytku resursnogo potencialu sil's'kyh terytorij: zagal'ni aspekty [State regulation of rural potential resource development: general aspects]. Ekonomika. Finansy. Menedzhment: aktual'ni pytannja nauky i praktyky - Economy. Finances. Management: topical issues of science and practice. № 4, pp. 19 - 30 [in Ukrainian].

4. Onjegina V.M., Shybajeva N.V. (2016). Instytucijna osnova agrarnoi' polityky: ukrai'ns'ki realii' j dosvid SShA ta JeS [Institutional Basis for Agrarian Policy: Ukrainian Realities and US and EU Experience]. Ekonomika APK - Economy AIC. № 1, pp. 17 -23 [in Ukrainian].

5. Rossoha V.V., Sharapa O.M. (2016). Instytucijne zabezpechennja upravlinnja gospodars'koju dijal'nistju agrarnyh pidpryjemstv [Institutional support for managing the economic activity of agricultural enterprises]. Ekonomika APK - Economy AIC. № 10, pp. 73 - 82 [in Ukrainian].

6. Sil's'ke gospodarstvo Ukrai'ny: statystychnyj zbirnyk [Agriculture of Ukraine]. Statistical compilation.(2019). Kyi'v, p. 235 [in Ukrainian]

7. Furman I.V., Pron'ko L.M. (2019). Formuvannja derzhavnoi' programy pidtrymky pidpryjemstv-agrovyrobnykiv Ukrai'ny $\mathrm{z}$ urahuvannjam svitovogo dosvidu [Formation of the state program of support of agricultural enterprises of Ukraine in the light of world experience]. Ekonomika APK - Economy AIC. № 11, pp. 85 - 89 [in Ukrainian]. 
8. Shybajeva N.V., Kvjatko T.M. (2015). Evoljucija spil'noi' agrarnoi' polityky JeS [Evolution of the EU common agricultural policy]. Visnyk Harkivs'kogo nacional'nogo tehnichnogo universytetu sil's'kogo gospodarstva imeni Petra Vasylenka - Bulletin of the Kharkiv National Technical University of Agriculture named after Peter Vasylenko. Vol. 162, pp. $306-315$ [in Ukrainian].

9. Shubravs'ka O.V. (2014). Agroprodovol'chyj rozvytok Ukrai'ny v konteksti global'nyh vyklykiv [Agri-food development of Ukraine in the context of global challenges]. Ekonomika APK - Economy AIC. № 7, pp. 52-58 [in Ukrainian].

10. Jurchenko A.D. (2016). Derzhavne reguljuvannja agrarnoi' sfery SShA [State regulation of the US agricultural sector]. Ekonomika APK - Economy AIC. № 1, pp. 92 - 96 [in Ukrainian].

11. Bondarevska K. (2014). State regulation as a factor of sustainable economic development. MEST Journal. Vol. 2. №. 2, pp. 23-31[in English].

12. Perepeczko B. (2005). Agriculture in the contemporary social mirror. The central european journal of social sciences and humanities. № 3(128), pp. 80-87 [in English].

Poperechny Stepan, Salamin Oksana Stepan Gzhytskyi National University of Veterinary Medicine and Biotechnologies Lviv

\section{ACTUAL PROBLEMS OF STATE REGULATION OF AGRICULTURE OF UKRAINE}

The purpose of the article is to substantiate the ways of improving the state regulation of agriculture in the conditions of intensification of international integration processes. The relevance of the study is determined by the lack of common approaches to the development and implementation of state regulatory policy, the borrowing of ways to regulate agriculture in economically developed countries without consideration of the state of the domestic agricultural market and the problems that need to be addressed. Common research methods were used. The monograph method was used to study the problems of regulatory policy development, statistical analysis - to study the volatility of product prices and their impact on production volumes. The results of the research compare different ways of state regulation of agriculture. Inadequate effectiveness of promoting the development of farms has been shown by simplifying the procedure of their state registration, the possibility of creating such farms without registration as a legal entity. Direct government financial subsidies did not have a significant impact on the development of farms. In the context of market relations, the decisive regulatory impact on economic entities is price, which is a main element of the market mechanism for regulating economy. Agricultural producers cannot adapt to the high level of price volatility. A highrisk market environment is emerging. Bank loans are not involved in this environment. The funds are not invested in an industry with a long return on capital. It is proposed to direct the state regulatory policy to the formation of horizontal and vertical marketing systems, in which prices will stabilize without state regulation. On the basis of harmonization of requirements for raw materials, competitive products on the foreign market will be produced. It is proposed to focus direct state financial support on financing investment projects to strengthen the international competitiveness of agriculture. That provide meets international standards and sanitary requirements for product organization. This will overcome the general trend of scattering state support funds. They will focus on achieving the priority goals of agricultural development in the context of Ukraine's international integration. The practical importance lies in the possibility of using the proposed methods of agricultural regulation by the state authorities and economic entities.

Key words: state regulation of agriculture, self-regulating economic systems, price volatility, price regulation, state financial support for agriculture, farms.

JEL classification: L51, Q13, Q18. 